\title{
TRANSFORMASI PETANI MENJADI ENTREPRENEUR (STUDI KASUS PADA PROGRAM WIRAUSAHA MUDA PERTANIAN DI FAKULTAS PERTANIAN UNIVERSITAS PADJADJARAN)
}

\author{
Gema Wibawa Mukti ${ }^{1}$, Rani Andriani ${ }^{2}$, Pandi Pardian ${ }^{3}$ \\ 1,2,3Program Studi Agribisnis, Fakultas Pertanian, Universitas Padjadjaran \\ gema.wibawa@unpad.ac.id
}

\begin{abstract}
Abstrak
Petani masa kini dituntut memiliki jiwa kewirausahaan dan juga kemampuan manajemen usaha yang baik sehingga memiliki daya saing yang tinggi untuk menghadapi perubahan yang terjadi dalam dunia bisnis pertanian. Tantangan bagi sektor pertanian di Indonesia saat ini adalah memfasilitasi pengembangan wirausaha petani muda agar menjadi petani modern di masa depan. Penelitian ini bertujuan untuk mengetahui transformasi petani sebagai hasil dari proses pendidikan kewirausahaan yang diberikan kepada petani muda terdidik. Mereka adalah lulusan Perguruan Tinggi (Fakultas Pertanian, Universitas Padjadjaran) yang mengikuti Program Wirausaha Muda Pertanian (PWMP). Hasil penelitian menunjukkan bahwa pengembangan kompetensi kewirausahaan dapat diarahkan kepada petani muda terdidik yang memiliki semangat yang besar untuk berkembang. Petani muda yang berasal dari lulusan Perguruan Tinggi menjadi sangat potensial karena umumnya mereka memiliki keberanian mengambil risiko, mampu mengenali kelebihan atau potensi dirinya, selalu berorientasi pada proses dan hasil, adaptif terhadap perubahan, selalu berinovasi untuk kemajuan usahanya, bersedia untuk berjejaring dan berkolaborasi secara positif dengan pihak lain sehingga semua pihak dapat berkembang dan sukses secara bersama - sama, selalu membangun jaringan usaha (silaturahmi) dengan mitra dan stakeholder.
\end{abstract}

Kata kunci: Wirausaha Muda, Kolaboratif, Transformasi, Petani Muda

\begin{abstract}
Modern farmers must have an entrepreneurial spirit as well as good business management skills so it has a high competitiveness to cope with business changes. The challenge for the agricultural sector in Indonesia at this time is to facilitate the development of young entrepreneur farmers to become a modern farmer in the future. This study aims to determine the transformation of farmers as a result of the entrepreneurship education process provided to educated young farmers. They are graduates of Higher Education (Faculty of Agriculture, Padjadjaran University) who follow the Programe. The results show that the development of entrepreneurial competence can be directed to educated young farmers who have a great passion to be an entrepreneurial farmers. Young become very potential because generally they have the courage to take risks, be able to recognize their strengths or potentials, always oriented to process and outcomes, adaptive to change, always innovate for the progress of their business, willing to network and collaborate positively with other parties so that all parties can grow and succeed together, always build a business network with partners and stakeholders.
\end{abstract}

Keywords: Young Entrepreneur, Collaborative, Transformation, Young Farmers 


\section{PENDAHULUAN}

Pembangunan bidang pertanian yang berkelanjutan memerlukan pengembangan kewirausahaan dan juga kompetensi petani. Budaya kewirausahaan dalam sektor pertanian telah diakui sebagai faktor penting dalam proses pembangunan pertanian (Bergevoet et al., 2005; McElwee \& Bosworth, 2010). Pada beberapa negara di Eropa, pendidikan kewirausahaan pada petani ternyata memberikan kontribusi yang positif terhadap pengembangan kewirausahaan pada petani yang bertujuan untuk menumbuhkan pembangunan pertanian serta kesejahteraan petani (Marsden \& Smith, 2005).

Pertanian adalah sektor yang sangat bergengsi karena sangat dibutuhkan oleh masyarakat, namun kondisi saat ini pertanian masih kurang diminati oleh kalangan generasi muda karena masih adanya stigma bahwa pertanian adalah "miskin" dan belum mampu memberikan kepastian bagi kehidupan para pelakunya di masa yang akan datang. Pertanian adalah sektor yang sangat heterogen, dimana petani yang beroperasi dalam suatu lingkungan yang kompleks dengan beragam permasalahan yang "unik. Kondisi ini menjadi penghalang bagi petani dalam melaksanakan aktivitas kewirausahaan (Carter, 2003; McElwee, 2008a). Pemahaman generasi muda yang terbatas mengenai sektor pertanian, juga menjadi penghalang bagi mereka untuk terjun dalam bidang pertanian. Lulusan Fakultas Pertanian yang diharapkan menjadi tenaga kerja handal yang kompeten dalam bidang pertanian ternyata belum seluruhnya tertarik untuk bergerak dalam bidang pertanian. Para lulusan ini sangat memahami pertanian, termasuk risiko yang ada di dalamnya, sehingga mereka memilih berkarir di luar bidang pertanian. Jadi mereka belum berkarir di bidang pertanian bukan karena mereka tidak ahli di dalamnya, namun justru karena mereka sangat memahami Pertanian (Mukti Gema, 2017). Fenomena ini menjadi sangat menarik ketika tenaga terdidik yang diharapkan dapat memajukan sektor pertanian justru lebih memilih untuk bekerja di luar sektor pertanian.

Penelitian - penelitian yang berkaitan dengan pengembangan kompetensi kewirausahaan dan organisasi pada petani di Indonesia sebagai negara berkembang khususnya masih sangat kurang. Meskipun dalam penelitian di beberapa negara maju menunjukkan bahwa aspek kewirausahaan ini sangat penting dalam pembangunan pertanian, terutama dalam hal strategi bisnis, kemampuan wirausaha petani, perilaku asosiatif petani dan organisasi petani (Bruton, Ahlstrom, \& Obloj, 2008; Carter, 2003; McElwee, 2006). Tantangan penting bagi sektor pertanian di Indonesia sebagai negara berkembang adalah memfasilitasi pengembangan wirausaha bagi petani, terutama petani muda yang menjadi harapan di masa yang akan datang. Tentunya kondisi ini membutuhkan dukungan dari semua pihak, terutama dalam hal pendidikan bagi petani agar dapat menjadi seorang wirausaha yang kreatif dan cerdas dalam mengembangkan usahanya sendiri, kelompok dan juga komunitas nya. (McElwee, 2006).

Penelitian ini bertujuan untuk mengetahui manfaat dari pendidikan kewirausahaan yang diberikan kepada generasi muda yang telah berperan sebagai petani maupun mereka yang tertarik untuk menjadi petani. Salah satu program pendidikan kewirausahaan pada petani yang dilihat adalah program dari Badan Penyuluhan dan Pengembangan Sumberdaya Manusia 
Pertanian (BPPSDMP) Kementerian

Pertanian Republik Indonesia, yaitu Program Wirausaha Muda Pertanian (PWMP). Tujuan dari penelitian adalah untuk menganalisis manfaat dari program PWMP ini bagi pesertanya yang terdiri dari alumni Perguruan Tinggi untuk menjadi petani dan juga mahasiswa yang berusaha dalam bidang pertanian. Pengembangan kompetensi kewirausahaan pemuda tani dalam program PWMP ini diharapkan dapat meningkatkan keunggulan kompetitif yang berkelanjutan sehingga mereka dapat bekerja dengan baik dan kompetitif dalam bidang usaha pertanian yang sedang mereka jalankan. Penelitian ini juga bertujuan untuk melihat perubahan aspek kewirausahaan dari para peserta sehingga diharapkan dapat memberikan kontribusi dalam pengembangan usaha pertanian yang dimiliki oleh peserta.

\section{KERANGKA TEORITIS}

Dalam beberapa tahun terakhir, para pelaku agribisnis, pemerintah dan Perguruan Tinggi telah menyadari pentingnya kewirausahaan dalam bisnis pertanian. McElwee (2006) menyatakan bahwa pertanian harus mulai terspesialisasi dan terdiversifikasi secara selektif berdasarkan permintaan pasar yang terkelola dengan baik (well manage). Kenyataan ini telah menjadi suatu keniscayaan yang tidak dapat dihindari apabila petani ingin bertahan dalam pasar global saat ini. Petani dituntut tidak hanya mahir dalam proses produksi saja, namun mereka harus memiliki kemampuan manajemen yang baik dalam mengelola usahatani mereka sendiri. Salah satu contoh untuk efisiensi biaya dalam usahatani misalnya dengan cara kolaborasi usaha dalam kelembagaan kelompok tani, adalah manajemen usaha yang dapat dilakukan oleh petani secara serius (van der Ploeg, 2000).

Shilul (2014) menyatakan bahwa, pembangunan berkualitas dapat dicapai dengan Pendidikan dan kewirausahaan yang dilakukan oleh masyarakatnya. Pembangunan yang berkelanjutan pada prinsipnya adalah suatu proses pembangunan manusia secara inklusif, sistemik, adil, bijaksana dan aman. Dalam pelaksanaannya, pembangunan berkelanjutan sangat tergantung kepada aspek ekologi, sosial dan ekonomi (Galdwin, Kennelly, \& Krause, 1995), yang sangat membutuhkan sumberdaya manusia yang handal (Rudmann, Vesala, \& Jäckel, 2008), untuk mendorong keberhasilan dalam pembangunan berkelanjutan. Dalam pembangunan pada sektor pertanian, petani adalah pihak yang paling bertanggung jawab atas kemajuan mereka sendiri, dengan mengadopsi prinsip, nilai, sikap dan perilaku baru (entrepreneurial behavior). McElwee (2008b) mengidentifikasi dua jenis petani dilihat dari sisi kewirausahaannya. Pertama, petani sebagai petani, yaitu petani yang cenderung melakukan diversifikasi produk yang masih terbatas dan masih bergantung pada faktor pendorong. Strategi usahanya didasarkan pada efisiensi biaya dan maksimasi harga jual, belum berorientasi pasar, masih berorientasi produk serta berbisnis atas dasar individualistik, belum bekerja dalam kelompok atau komunitas petani. Kedua, petani sebagai entrepreneur, yaitu petani yang mampu untuk mengidentifikasi dan mengeksploitasi peluang - peluang pasar yang ada dan bernilai tinggi dengan memanfaatkan sumber daya pertanian yang dimiliki oleh petani dengan cara yang fleksibel dan inovatif. Mengembangkan kompetensi kewirausahaan di bidang pertanian, berarti mengajak petani untuk 
berubah dari petani konvensional menjadi petani pengusaha melalui suatu proses pendidikan.

Barney (1991) menjelaskan bahwa dari sisi sumberdaya, seorang entrepreneur akan mampu berkompetisi dengan apa yang dia kembangkan, dan akan tetap menjaga keunikan mereka sehingga menjadi suatu keuntungan bagi mereka dan mengurangi risiko usaha mereka. Schumpeter (2005) mengatakan bahwa seorang entrepreneur akan selalu melakukan kombinasi kombinasi baru dalam usaha mereka sehingga posisi mereka di benak konsumen akan selalu "baru".

Petani yang berperan sebagai pengusaha tidak hanya ahli dalam proses produksi, namun mereka memiliki kemampuan manajerial usaha yang visioner berorientasi hasil. Baker \& Sinkula (2009) mengatakan bahwa seorang pengusaha memiliki orientasi kewirausahaan dan pasar, sehingga mereka akan selalu konsisten dalam melakukan inovasi produk dan juga pasar, selalu berani mengambil keputusan yang sifatnya proaktif serta berani mengambil risiko (dalam Basso, Fayolle, \& Bouchard, 2009; Covin \& Slevin, 1988; 1989; Miller, 1983; Kreiser, Marino, \& Weaver, 2002). Ketiga dimensi yang disebutkan diatas, telah diakui oleh dunia internasional sebagai aspek penting dalam aktivitas usaha dalam pertanian (Lauwere, 2004; Nieuwenhuis, 2002; Pyysiäinen, Anderson, McElwee, \& Vesala, 2006; Rudmann, Vesala, \& Jäckel, 2008).

Orientasi pasar didefinisikan sebagai kemauan individu atau organisasi untuk senantiasa memberikan nilai lebih kepada pelanggan. Segala aktivitas usaha nya didasarkan pada kebutuhan dan keinginan pasar, sehingga seorang pengusaha selalu memiliki komitmen yang kuat untuk senantiasa mencari informasi mengenai pasar yang ditujunya (Han, Kim, \& Srivastaba, 1998). Orientasi kewirausahaan dan pasar membantu petani untuk mengidentifikasi peluang pasar dan merencanakan tindakan strategis yang harus dilakukan untuk menjawab peluang tersebut sehingga petani dapat berbisnis dengan sukses (McElwee, 2008b).

Petani di Indonesia umumnya dan di Jawa Barat khususnya rata - rata memiliki luasan lahan yang sempit dengan kepemilikan lahan rata-rata 0,2 - $2 \mathrm{Ha}$. Kondisi ini tentu menjadi faktor penghambat bagi petani untuk menembus pasar, karena kapasitas produksi yang terbatas sehingga petani selalu memiliki posisi tawar yang lemah dengan pihak pasar. Petani perlu bekerjasama diantara mereka dalam bentuk kelompok atau gabungan kelompok sehingga mereka dapat berproduksi lebih efisien, mampu berhadapan dengan pedagang perantara dan pasar dengan lebih kuat (McElwee, 2006; 2008b). Berusaha, berbisnis dan berjeraring bersama - sama menjadi suatu tuntutan bagi petani dalam menjalankan usaha mereka sebagai suatu tindakan rasional bagi petani dengan skala usaha kecil sehingga mereka dapat memasuki pasar dengan efisiensi kolektif (Mesquita \& Lazzarini, 2008; Svetlicic, Jaklic, \& Burger, 2007).

Petani yang berjiwa wirausaha dan berorientasi pasar memiliki kemampuan untuk menggunakan jejaring sebagai faktor penting dalam bisnis mereka. Dalam proses pengembangan kompetensi tersebut, petani harus mengurangi ketergantungan terhadap subsidi pemerintah, merespons meningkatnya permintaan akan kualitas, dan menghormati lingkungan alam (McElwee, 2008b).

(McElwee, 2006) menyatakan bahwa pengembangan kompetensi kewirausahan 
di petani bisa menjadi masalah, karena pengembangan kompetensi ini lebih merupakan sebuah seni daripada sains. Namun demikian, pendidikan

kewirausahaan masih sangat dibutuhkan oleh petani di Indonesia. Pertanian dengan pelaku yang sangat heterogen tentunya menjadi tantangan tersendiri bagi proses pengajaran kewirausahaan kepada petani (Carter, 2003; McElwee, 2006; 2008a; Pyysiäinen, Anderson, McElwee, \& Vesala, 2006; Vesala, Peura, \& McElwee, 2007). Latar belakang dan profil seseorang (persepsi dirinya sendiri, budaya, struktur sosial dan kelembagaan) dapat sangat mempengaruhi kemampuannya untuk belajar dan mengembangkan kompetensi kewirausahaan dan organisasi (Dana \& Dana, 2007; Pyysiäinen, Anderson, McElwee, \& Vesala, 2006; Rudmann, Vesala, \& Jäckel, 2008; Vesala, Peura, \& McElwee, 2007; Vesala \& Vesala, 2010).

Lauwere (2004) dalam penelitiannya menemukan bahwa kritik, ketekunan, kepemimpinan, kreativitas, inisiatif, dan orientasi pasar secara positif mempengaruhi kewirausahaan di bidang pertanian; Sementara sikap pasif atas suatu kemajuan memiliki efek negatif bagi pengembangan dalam bidang pertanian. Carter (2003) dan juga McElwee \& Bosworth, 2010), menyebutkan bahwa saat ini pertanian akan lebih baik apabila dikerjakan oleh generasi muda, karena petani yang lebih muda dan terlatih lebih baik dalam aktivitas bisnis yang lebih beragam, cenderung memiliki sikap positif terhadap peluang pasar yang baru, lebih peka terhadap Kebutuhan pelanggan, dan lebih siap untuk untuk terlibat dalam usaha baru.

\section{METODE PENELITIAN}

Penelitian ini menggunakan eksperimen alami yang bertujuan untuk mengeksplorasi tahap awal proses pendidikan kewirausahaan petani muda yang merupakan lulusan dari Perguruan Tinggi, khususnya dari Fakultas Pertanian. Penelitian dilakukan kepada peserta program pendidikan kewirausahaan yang diselenggarakan oleh Kementerian Pertanian yang bekerjasama dengan Perguruan Tinggi Mitra dan Sekolah Tinggi Pertanian.

Untuk mengeksplorasi proses awal Program Wirausaha Muda Pertanian, maka dilakukan observasi, wawancara mendalam dan proses pendampingan kepada para petani muda lulusan Fakultas Pertanian yang mengikuti Program Wirausaha Muda Pertanian. Proses penelitian dilakukan pada bulan April - Desember Tahun 2016. Total peserta yang menjadi objek penelitian adalah sebanyak 45 orang peserta program PWMP

Desain penelitian yang digunakan dalam penelitian ini adalah deskriptif eksploratif. Penelitian deskriptif eksploratif bertujuan untuk menggambarkan keadaan suatu fenomena, dalam penelitian ini tidak menguji hipotesis tertentu tetapi untuk menggambarkan apa adanya suatu variabel, gejala atau keadaan (Arikunto, 2002). Fenomena yang digambarkan dalam penelitian ini adalah proses tranformasi peserta PWMP dari petani menjadi seorang pengusaha atau entrepreneur. Teknik penelitian yang digunakan dalam penelitian ini adalah teknik studi kasus, yaitu penelitian dengan pendekatan yang bertujuan mempertahankan keutuhan (wholeness) objek penelitian. Penelitian studi kasus bersifat mendalam dan mendetail maka studi kasus pada umumnya menghasilkan gambaran yang longitudinal, yaitu hasil pengumpulan dan analisis data dalam jangka waktu tertentu, (Sugiyono, 2012). Sumber data yang 
digunakan dalam penelitian ini berupa data primer dan data sekunder.

Data yang ada dianalisis dengan proses penyederhanaan data ke dalam bentuk yang mudah dibaca dan diinterpretasikan. Data disajikan secara deskriptif dan sesuai dengan tujuan penelitian yaitu untuk mengetahui proses transformasi petani menjadi entrepreneur dalam Program Wirausaha Muda Pertanian pada peserta dari Fakultas Pertanian Unpad. Hasil wawancara dan observasi kemudian dikelompokkan ke dalam beberapa kategori, seperti model atau bentuk usaha peserta, aspek kepemimpinan, aspek pemasaran, aspek produksi dan manfaat PWMP bagi peserta.

\section{HASIL DAN PEMBAHASAN}

\section{Program Wirausaha Muda Pertanian}

Badan Penyuluhan dan Pengembangan

Sumberdaya Manusia Pertanian (BPPSDMP) Kementerian Pertanian Republik Indonesia mendorong generasi muda untuk menjadi wirausahawan di bidang pertanian. Tantangan bidang pertanian salah satu nya adalah menurunnya minat pemuda atau generasi muda untuk berwirausaha pada sektor pertanian. Sektor pertanian masih dianggap sebagai sektor yang miskin, kotor, berlumpur, terbelakang dan tidak menarik untuk kepastian masa depan ${ }^{1}$. Kenyataan saat ini sebagian besar lulusan Perguruan Tinggi berorientasi untuk mencari

\footnotetext{
1 Disampaikan oleh Gunawan, Kepala Badan Penyuluhan dan Pengembangan Sumberdaya Manusia Pertanian (BPPSDMP) Kementerian Pertanian Republik Indonesia pada kegiatan monitoring dan evaluasi program penumbuhan wirausahawan muda pertanian (PWMP) di Yogyakarta pada tanggal 4 Oktober Tahun 2016
}

pekerjaan di daerah perkotaan karena dianggap lebih menjanjikan untuk masa depan, selain itu pola pembelajaran di Perguruan Tinggi yang mempersiapkan lulusannya untuk cepat bekerja, bukan menciptakan pekerjaan.

Sikap paternalistik pemerintah terhadap sektor pertanian dalam pembangunan pertanian di Indonesia ternyata menghambat munculnya sikap kewirausahaan dari petani dan generasi muda terhadap pertanian. Sikap paternalistik menyebabkan petani menjadi tergantung terhadap segala bantuan pemerintah, sehingga petani menjadi terbiasa untuk "dilayani". Petani terbiasa untuk mengikuti apa yang diinginkan oleh pemerintah, bukan mengikuti keinginan pasar. Pemerintah memberikan dukungan kepada petani yang dianggap sebagai pihak yang miskin, tidak mampu, yang menyebabkan munculnya anggapan bahwa pertanian memang tidak mampu untuk hidup sendiri tanpa bantuan dari pihak lain. Generasi muda melihat kenyataan ini sebagai sesuatu yang tidak menarik bagi mereka, tidak memberikan prospek yang baik bagi masa depan mereka sehingga mereka lebih memilih untuk berkarir di sektor non pertanian.

Kementerian Pertanian melihat kondisi tersebut merupakan suatu tantangan bagi pertanian Indonesia di masa depan.

Indonesia yang diprediksi akan mendapatkan bonus demografi pada tahun 2035 , tentunya harus mempersiapkan diri agar pada saatnya nanti, Indonesia akan benar-benar mendapatkan keuntungan dari bonus demografi tersebut, terutama dalam bidang pertanian yang akan didominasi oleh orang muda, sehingga diharapkan pada saatnya akan mengangkat pertanian Indonesia. Dalam mengejar tujuan tersebut, Program Wirausaha Muda Pertanian berusaha membidik mahasiswa 
dan juga fresh graduate yang berumur 2027 tahun, yang berasal dari Sekolah Tinggi Pertanian dan Perguruan Tinggi yang memiliki Jurusan bidang pertanian. Diharapkan pada tahun 2035 mereka menjadi tulang punggung pembangunan bidang pertanian di Indonesia.

Model pengembangan yang dilakukan berpusat pada pelaku dan calon pelaku usaha pertanian yang terdidik.

Pengembangan aspek kewirausahaan dilakukan melalui proses pendidikan yang terstruktur dan sesuai dengan tuntutan pasar pertanian, sehingga peserta dapat memperoleh teori sekaligus aplikasi nyata dalam bisnis pertanian yang sesungguhnya. Pendekatan teoritis kepada peserta adalah untuk memberikan kesempatan bagi mereka untuk mengembangkan daya nalar dan analisisnya dalam aktivitas bisnis pertanian yang mereka lakukan. Praktek langsung di lapangan dengan dukungan dana yang diberikan oleh Kementerian Pertanian kepada peserta bertujuan agar peserta mampu menerapkan daya nalar dan analisisnya tadi dalam aktivitas bisnis secara nyata sehingga mereka dapat merasakan langsung manfaatnya bagi diri mereka sendiri dan juga masyarakat sekitar. Pemberian dukungan dana dimaksudkan agar peserta mampu mengoperasionalkan ide dan analisis usahanya dalam bentuk nyata, sehingga mereka tidak hanya "berkhayal" dalam berbisnis, namun mampu menjalankan bisnisnya sesuai dengan rencana mereka sebelumnya. Bernard Lonergan (2001) mengatakan bahwa dalam konteks pengembangan aspek kewirausahaan, terdapat empat hal yang harus dipenuhi, yaitu aspek empiris, intelektual, rasional dan bertanggungjawab. Apabila diaplikasikan dalam proses belajar, maka dalam program ini peserta diajak untuk memperkuat level teori dan manajemen usaha (pra usaha), kemudian dilanjutkan dengan aplikasi yang strategis serta memiliki rasa tanggung jawab dalam menjalankan usahanya tersebut.

Dalam Program Wirausaha Muda Pertanian, bantuan lebih diarahkan pada mahasiswa dan alumni dalam bentuk kelompok, sehingga diharapkan manfaat program dapat dirasakan oleh lebih banyak peserta dan dampaknya akan dirasakan lebih luas di masyarakat. Dalam program ini, setiap kelompok yang terdiri dari 3-5 orang diberikan pendampingan yang dilakukan oleh dosen pendamping selama tiga tahun pertama fase usaha mereka. Pendamping ini bertindak sebagai agen pengembangan kewirausahaan dari peserta program. Dalam pelaksanaannya, pendamping melakukan proses pendidikan kewirausahaan yang meliputi persiapan, pelatihan manajemen bisnis, pengorganisasian, kegiatan magang peserta dan pelaksanaan di lapangan dengan mengutamakan kerjasama dalam tim.

Program Wirausaha Muda Pertanian dimulai pada tahun 2016 dengan peserta dari Sekolah Tinggi Penyuluhan Pertanian (STPP) dan Perguruan Tinggi Mitra, salah satu nya adalah Fakultas Pertanian Universitas Padjadjaran. Jumlah peserta program ini adalah 15 kelompok yang per kelompok berjumlah 3 orang, sehingga total peserta adalah 45 orang. Kriteria peserta program PWMP adalah (1) lulusan Fakultas Pertanian yang memiliki passion atau sedang menjalankan usaha dalam bidang pertanian, (2) dengan sukarela mengikuti program sehingga mereka dapat mengikuti seluruh rangkaian program dengan sungguh - sungguh, tidak ada unsur keterpaksaan dalam menjalankan nya.

Program ini bertujuan untuk (1) menyadarkan aspek kewirausahaan peserta 
dan menumbuhkannya dengan pelatihan dan pendampingan dan (2) Kemandirian peserta dalam menjalankan usaha dalam bidang pertanian. Berikutnya akan dijelaskan perubahan yang dialami peserta selama mengikuti program pwmp ini dan manfaatnya bagi usaha mereka sehingga dapat menjadi evaluasi bagi kelanjutan program selanjutnya.

\section{Pola Pikir Kewirausahaan Peserta Program Sebagai Petani}

Peserta program dalam penelitian ini adalah lulusan dari Fakultas Pertanian Universitas Padjadjaran, sehingga mereka layak disebut sebagai Tenaga Kerja Pertanian yang terdidik. Pada dasarnya para peserta telah memiliki bekal ilmu yang memadai, terutama dalam aspek produksi. Alasan utama mereka terjun ke dunia pertanian sebagai petani adalah mereka menguasai teknik produksi yang memadai sehingga mereka memiliki kepercayaan diri yang baik untuk memulai usaha dalam bidang pertanian. Peserta program sebagian besar adalah lulusan yang memiliki passion untuk berwirausaha dalam bidang pertanian. Mereka melihat potensi pertanian yang sangat menjanjikan di masa yang akan datang, sehingga mereka memutuskan untuk mencoba wirausaha di bidang pertanian.

Dalam aspek produksi, para peserta ini telah menerapkan sistem pertanian modern yang mengedepankan kualitas produksi yang baik, namun dari pengamatan yang dilakukan, dalam menjalankan usahanya sebagian besar para lulusan Perguruan Tinggi ini masih berorientasi pada produk, belum berorientasi pasar. Dalam menjalankan bisnisnya, mereka masih berbisnis atas dasar individualistik, belum berwirausaha atas dasar kelompok atau komunitas. Mereka masih melihat sesama petani adalah pesaing yang harus mereka "kalahkan", termasuk teman - teman mereka sendiri sesama lulusan Perguruan Tinggi. Untuk "mengalahkan" pesaingnya, mereka berusaha untuk melakukan efisiensi usaha dan maksimasi harga jual, sehingga tingkat keuntungan diharapkan dapat diperoleh semaksimal mungkin. Pola pikir bahwa usaha harus dilakukan sendiri dan melihat petani lain sebagai pesaing tentunya akan menghambat aktivitas bisnis mereka karena skala usaha yang kecil (kurang dari 0,5 Ha), sehingga mereka akan selalu kesulitan untuk menembus pasar yang lebih baik. Pemahaman bisnis tersebut disebabkan oleh masih terbatasnya akses mereka terhadap pasar dan pemahaman akan pentingnya kelompok atau komunitas dalam berwirausaha.

Apabila melihat kepada aktivitas produksi, para peserta program telah mampu menerapkan ilmu usahatani (on farm) yang mereka peroleh selama belajar di Perguruan Tinggi, namun hal tersebut belum didukung oleh pengelolaan usaha yang professional dan berorientasi pasar. Umumnya peserta kurang memahami pentingnya manajemen usaha yang tepat bagi usaha mereka. Dalam Program Wirausaha Muda Pertanian, peserta diperkenalkan kepada manajemen usaha dalam bisnis pertanian, sehingga diharapkan peserta dapat menjalankan usahanya dengan baik dan mampu berkembang secara berkelanjutan serta memberikan dampak yang positif bagi lingkungan sekitarnya.

Dalam Program Wirausaha Muda Pertanian juga, peserta diberikan pemahaman mengenai prinsip, nilai dan aspek manajemen usaha yang diperlukan agar mereka dapat sukses sebagai pengusaha. Kondisi ini sesuai dengan pernyataan McElwee (2008), bahwa pengusaha sukses selalu memiliki prinsip, nilai dan juga sikap yang baru dalam 
aktivitas usaha mereka, sehingga usaha mereka tersebut dapat senantiasa bertahan dan berkembang dengan nyata dan juga berkelanjutan.

\section{Pola Pikir Peserta Sebagai Seorang Entrepreneur}

Pengembangan pertanian tentu tidak lepas dari pengembangan individu petani sebagai seorang pengusaha. Dumasari (2014) menjelaskan bahwa petani belum memiliki semangat dan kemampuan manajemen usaha yang kuat, sehingga kondisi ini menjadi salah satu penyebab pengembangan potensi diri petani menjadi terhambat. Faktor ini juga menjadi salah satu penyebab kondisi social ekonomi petani sulit untuk berkembang ke arah yang lebih positif.

Tuntutan pasar produk pertanian saat ini menuntut petani untuk berubah dan memiliki sikap yang lebih positif terhadap aktivitas ekonomi mereka (McElwee \& Bosworth, 2010). Kreativitas petani menjadi aspek penting dalam aktivitas bisnis mereka, yaitu proses dimana petani menjadi lebih berorientasi pasar dan kewirausahaan sehingga arah usaha mereka selalu berorientasi pada pengembangan usaha yang berkelanjutan (Lauwere, 2004; Rudmann, Vesala, \& Jäckel, 2008). Selain itu organisasi petani juga diharapkan dapat berkembang karena tuntutan bisnis saat ini mengharuskan petani berkelompok, sehingga mereka mampu "menghadapi" pelaku usaha (pasar) yang memiliki modal yang besar. Dengan berkelompok, mereka memiliki daya tawar yang lebih baik dan memiliki kemampuan untuk menentukan harga jual produk mereka.

Kemampuan petani mampu melihat pasar dan merespon pasar dengan baik diharapkan muncul dari petani terdidik, yang salah satunya adalah petani yang berasal dari lulusan Perguruan Tinggi. Program Wirausaha Muda Pertanian ini mendorong para lulusan terdidik dari Sekolah Tinggi Penyuluhan Pertanian dan Perguruan Tinggi agar mereka menjadi petani yang kompetitif, professional dan mampu memberikan perubahan positif bagi dirinya dan juga masyarakat sekitar.

Berikut adalah beberapa perubahan atau transformasi yang dirasakan oleh peserta Program Wirausaha Muda Pertanian setelah mengikuti program selama 2(dua) tahun. 
Tabel 1.

Transformasi Peserta Program Wirausaha Muda Pertanian Lulusan Fakultas Pertanian UNPAD, Dari Seorang Petani Menjadi Seorang Entrepreneur

\begin{tabular}{|c|c|c|}
\hline Topik & Peserta Sebagai Petani & Peserta Sebagai Entrepreneur \\
\hline Pasar & $\begin{array}{l}\text { Peserta memahami bahwa mereka adalah } \\
\text { petani dengan latar belakang pendidikan } \\
\text { di bidang pertanian yang memiliki } \\
\text { kompetensi yang berhubungan dengan } \\
\text { usaha mereka dalam bidang pertanian, } \\
\text { baik dari sisi onfarm maupun dari sisi off } \\
\text { farm (pemasaran). Dengan latar belakang } \\
\text { tersebut, diharapkan para petani peserta } \\
\text { program menjalankan usahanya dengan } \\
\text { berorientasi pasar. Namun pada } \\
\text { kenyataannya di lapangan, para peserta } \\
\text { belum memiliki pasar yang memadai, } \\
\text { sehingga mereka masih berorientasi } \\
\text { produk dan baru memikirkan pasar } \\
\text { setelah mereka berproduksi. } \\
\text { Dalam usahatani mereka, peserta menjual } \\
\text { produk kepada pembeli yang menawar } \\
\text { lebih tinggi, belum melihat kesepakatan } \\
\text { dalam volume dan harga sebagai prioritas } \\
\text { dalam pemasaran produk mereka. Peserta } \\
\text { masih melihat petani lain sebagai pesaing } \\
\text { bagi mereka dalam hal pemasaran hasil } \\
\text { panen. Beberapa peserta berpikir bahwa }\end{array}$ & $\begin{array}{l}\text { Peserta dituntut menjadi petani yang berjiwa entrepreneur, sehingga } \\
\text { bisnis mereka dapat terus berkembang secara berkelanjutan. Setelah } \\
\text { mengikuti program selama } 2 \text { tahun, peserta melihat pasar sebagai } \\
\text { dasar utama bisnis mereka. Produksi hanya akan dimulai apabila } \\
\text { telah didapatkan pasar yang jelas, sehingga potensi kerugian akibat } \\
\text { produk yang tidak terjual dapat dieliminir. } \\
\text { Peserta mulai melakukan hubungan jangka panjang dengan } \\
\text { perantara dan juga pasar atau konsumen langsung. Hubungan ini } \\
\text { dilakukan untuk mendapatkan kepastian pasar. Pasar yang pasti } \\
\text { tentunya dapat memberikan "kenyamanan" bagi pelaku usaha } \\
\text { dalam menjalankan usahanya. Peserta sebagai petani tidak lagi } \\
\text { hanya memproduksi produk pertanian kemudian menjualnya, } \\
\text { namun mulai menggeser cara berbisnisnya, yaitu dengan } \\
\text { memberikan jaminan pasokan kepada pembeli sedangkan pedagang } \\
\text { atau perantara menjamin harga. Hubungan yang saling } \\
\text { menguntungkan ini dalam jangka panjang dapat memberikan } \\
\text { kepastian usaha yang dapat memberikan profit yang menjanjikan } \\
\text { dan yang paling utama adalah dapat diprediksi. Bisnis dengan profit } \\
\text { yang dapat diprediksi dapat menjaga keberlangsungan usaha } \\
\text { tersebut. Perluasan pasar menjadi suatu keniscayaan dalam bisnis, } \\
\text { karena suatu bisnis yang baik harus berkembang ke arah skala } \\
\text { usaha yang semakin besar, bukan sebaliknya. Pasar yang semakin } \\
\text { bertambah tentunya mendorong peserta untuk meningkatkan }\end{array}$ \\
\hline
\end{tabular}




\begin{tabular}{|c|c|c|}
\hline & $\begin{array}{l}\text { mereka perlu belajar bagaimana mulai } \\
\text { menciptakan nilai yang berbeda di mata } \\
\text { konsumen, meningkatkan kualitas dan } \\
\text { meraih pasar baru. Selama ini hal } \\
\text { tersebut belum dapat dilakukan karena } \\
\text { adanya keterbatasan informasi, link pasar } \\
\text { dan juga kemampuan manajemen usaha } \\
\text { yang masih terbatas. }\end{array}$ & $\begin{array}{l}\text { produksi dan juga kualitas sesuai dengan permintaan pasar. Setelah } \\
\text { mengikuti program peserta menjadi semakin terbuka dengan pasar } \\
\text { karena dalam program PWMP, peserta dipertemukan langsung } \\
\text { dengan pihak pasar, sehingga mereka dapat mendengar langsung } \\
\text { keinginan konsumen. }\end{array}$ \\
\hline $\begin{array}{l}\text { Aktivitas } \\
\text { Produktif }\end{array}$ & $\begin{array}{l}\text { Peserta yang memiliki latar belakang } \\
\text { pendidikan tinggi, tentu memiliki modal } \\
\text { yang kuat dalam berusaha dalam bidang } \\
\text { pertanian. Umumnya mereka bersedia } \\
\text { untuk belajar tentang produk yang } \\
\text { berbeda karena mereka memahami } \\
\text { bahwa diversifikasi menjadi penting, } \\
\text { selain untuk menjaga tanah tetap subur, } \\
\text { menghindari serangan hama, juga untuk } \\
\text { menjaga kualitas produk yang mereka } \\
\text { hasilkan. Peserta juga mengetahui bahwa } \\
\text { mereka harus melakukan investasi dalam } \\
\text { usaha mereka jika mereka ingin } \\
\text { berkembang. Alasan peserta mengikuti } \\
\text { Program Wirausaha Muda Pertanian } \\
\text { adalah sebagai salah satu bentuk investasi } \\
\text { agar mendapatkan jaringan yang baru } \\
\text { dalam usaha, dukungan dana dari } \\
\text { Kementerian Pertanian dan pengetahuan }\end{array}$ & $\begin{array}{l}\text { Peserta memahami bahwa investasi adalah sesuatu yang harus } \\
\text { mereka lakukan, karena dengan investasi maka usaha mereka dapat } \\
\text { berkembang. Pemikiran mengenai pengembangan usaha merupakan } \\
\text { salah satu ciri peserta telah bertransformasi menjadi entrepreneurial } \\
\text { farmer. } \\
\text { Program Wirausaha Muda Pertanian ini semakin memperkuat aspek } \\
\text { kewirausahaan peserta, mereka semakin memahami apa yang harus } \\
\text { mereka lakukan terhadap usaha mereka. Seperti misalnya membuat } \\
\text { jejaring usaha, mencari komunitas usaha dan memperkuat pasar } \\
\text { yang berkelanjutan. }\end{array}$ \\
\hline
\end{tabular}


Agricore Volume 3 Nomor 2, Desember 2018

\begin{tabular}{|c|c|c|}
\hline & $\begin{array}{l}\text { mengenai manajemen usaha. Sebagai } \\
\text { seorang pengusaha tentunya hal tersebut } \\
\text { menjadi suatu yang yang positif bagi } \\
\text { pengembangan diri nya sebagai seorang } \\
\text { petani. Para peserta ini juga selalu } \\
\text { memiliki keyakinan untuk mendapatkan } \\
\text { hasil yang lebih baik di masa depan, } \\
\text { sehingga mereka pun selalu mencari } \\
\text { informasi lebih banyak tentang pasar dan } \\
\text { sistem produksi yang efisien, } \\
\text { meningkatkan kualitas produk yang } \\
\text { mereka hasilkan. Petani usia muda, } \\
\text { peserta program PWMP ini pada } \\
\text { dasarnya telah berperan sebagai seorang } \\
\text { entrepreneur, karena mereka selalu } \\
\text { mendorong dirinya sendiri ke arah } \\
\text { kemajuan dan selalu meningkatkan } \\
\text { kemampuan diri untuk menjadi } \\
\text { pengusaha yang lebih baik. }\end{array}$ & \\
\hline $\begin{array}{l}\text { Kapasitas } \\
\text { Organisasi }\end{array}$ & $\begin{array}{l}\text { Bisnis yang dilakukan peserta umumnya } \\
\text { masih dilakukan secara individu, belum } \\
\text { melibatkan pihak lain. Pemahaman } \\
\text { bahwa petani lain merupakan pesaing } \\
\text { masih ada dalam konsep usaha para } \\
\text { peserta }\end{array}$ & $\begin{array}{l}\text { Program Wirausaha Muda Pertanian mensyaratkan berkelompok } \\
\text { bagi peserta yang mengikuti program ini. Tujuan pengelompokan } \\
\text { peserta ini agar manfaat program dapat dirasakan oleh lebih banyak } \\
\text { orang dan memberikan dampak positif bagi masyarakat di sekitar } \\
\text { tempat usaha. Manfaat yang paling dirasakan setelah program } \\
\text { adalah, peserta mendapatkan "jaringan" usaha baru dari sesama } \\
\text { peserta yang lain, dan menjadikan mereka sebagai mitra usaha, } \\
\text { tidak lagi pesaing seperti yang mereka lakukan sebelumnya. }\end{array}$ \\
\hline
\end{tabular}


Agricore Volume 3 Nomor 2, Desember 2018

Jurnal Agribisnis dan Sosial Ekonomi Pertanian UNPAD p-ISSN No. 2528-4576 / e-ISSN No. 2615-7411

\begin{tabular}{|c|c|c|}
\hline & & $\begin{array}{l}\text { Pemahaman mengenai pentingnya komunitas mulai muncul. } \\
\text { Komunitas tersebut menjadi wadah untuk mereka saling bertukar } \\
\text { informasi pasar, teknologi, sistem produksi, investasi dan } \\
\text { pengetahuan lainnya. }\end{array}$ \\
\hline Kepemimpinan & $\begin{array}{l}\text { Bekerja dalam grup dinilai tidak efisien } \\
\text { dalam suatu usaha, kecuali apabila setiap } \\
\text { individu dalam grup tersebut memiliki } \\
\text { peran dan fungsi yang jelas dalam gerak } \\
\text { usaha mereka. Selain itu, pengambilan } \\
\text { keputusan dalam grup dinilai lebih sulit } \\
\text { dibandingkan apabila mereka } \\
\text { menjalankan usaha sendiri. Sehingga } \\
\text { hampir } 80 \% \text { peserta menjalankan } \\
\text { usahanya secara individu, dan sisanya } \\
\text { menjalankan usaha secara berkelompok. } \\
\text { Mereka yang berkelompok menyadari } \\
\text { bahwa dalam berbisnis mereka } \\
\text { memerlukan personil dengan keahlian } \\
\text { yang beragam, yang saling melengkapi } \\
\text { dalam sebuah organisasi sehingga } \\
\text { organisasi tersebut dapat bergerak secara } \\
\text { dinamis dan memperoleh profit dari hal } \\
\text { tersebut. }\end{array}$ & $\begin{array}{l}\text { Setelah program, peserta masih tetap menganggap bahwa bekerja } \\
\text { sebagai suatu grup akan membebani mereka dalam menjalankan } \\
\text { usaha. Namun, mereka mulai menyadari keberadaan peserta lain } \\
\text { sebagai partner, bukan lagi pesaing. Mereka juga sudah mulai } \\
\text { membangun grup yang sesuai dengan kebutuhan usaha mereka. } \\
\text { Pengembangan komunitas pun mulai dipahami oleh peserta sebagai } \\
\text { suatu kebutuhan bagi usaha mereka, bukan lagi sebagai beban } \\
\text { seperti yang selama ini mereka rasakan. }\end{array}$ \\
\hline Manfaat PWMP & & $\begin{array}{l}\text { Secara umum, peserta telah belajar bahwa kualitas dan } \\
\text { komersialisasi adalah pendorong utama untuk mendapatkan } \\
\text { keuntungan. Mereka memahami bahwa dalam aktivitas bisnis, }\end{array}$ \\
\hline
\end{tabular}


Agricore Volume 3 Nomor 2, Desember 2018

Jurnal Agribisnis dan Sosial Ekonomi Pertanian UNPAD

p-ISSN No. 2528-4576 / e-ISSN No. 2615-7411

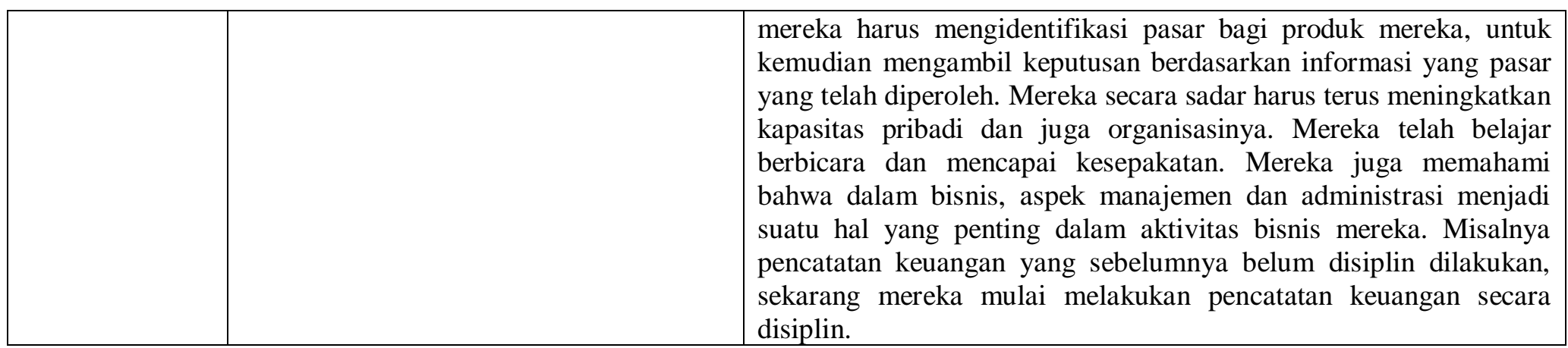

Sumber : Data Primer (Diolah) 


\section{PENUTUP}

Berkarir sebagai seorang petani, bagi sebagian masyarakat dianggap tidak menjanjikan dan identik dengan kemiskinan. Petani di Indonesia sebagian besar masih berorientasi pada produksi, sehingga mereka selalu berada pada posisi yang menerima harga, bukan penentu harga. Umumnya petani masih menganggap usahanya sebagai suatu rutinitas untuk pemenuhan kebutuhan hidupnya, sehingga mereka seringkali tidak berfikir untuk mengembangkan usahanya. Namun hal ini juga tidak sepenuhnya menjadi kesalahan petani, karena petani dengan segala keterbatasannya tentu sulit untuk mengembangkan usahanya. Transformasi petani menjadi seorang entrepreneur nampaknya menjadi suatu tuntutan yang tidak dapat dihindari apabila mereka ingin tetap bertahan dalam usahanya. Tentunya pengembangan kompetensi kewirausahaan dan manajemen usaha pada petani bukanlah tugas yang mudah untuk dilaksanakan. McElwee (2006; 2008b), mengemukakan bahwa pengembangan usaha petani sulit dilakukan karena skala usaha kecil, kekurangan modal, akses pasar yang terbatas, posisi tawar yang rendah, kemampuan manajemen usaha yang rendah, umur petani lebih dari 40 tahun dan kurangnya jiwa wirausaha. Pengembangan kompetensi kewirausahaan sulit apabila diterapkan pada petani dengan kriteria diatas, karena keterbatasannya tersebut membuat petani menjadi belum "berani" untuk berubah untuk berkembang. Pengembangan kompetensi kewirausahaan dapat diarahkan kepada petani muda, petani terdidik yang masih memiliki semangat yang besar untuk berkembang. Petani muda yang berasal dari lulusan
Perguruan Tinggi menjadi sangat potensial karena umumnya mereka memiliki keberanian mengambil risiko, mampu mengenali kelebihan atau potensi dirinya, selalu berorientasi pada proses dan hasil, adaptif terhadap perubahan, selalu berinovasi untuk kemajuan usahanya, bersedia untuk berjejaring dan berkolaborasi secara positif dengan pihak lain sehingga semua pihak dapat berkembang dan sukses secara bersama sama, selalu membangun jaringan usaha (silaturahmi) dengan mitra dan stakeholder yang terkait dengan usahanya.

Pengembangan kompetensi kewirausahaan pada generasi muda diharapkan Indonesia memiliki petani yang memiliki jiwa kewirausahaan yang kuat sehingga dapat memperkuat pembangunan pertanian secara keseluruhan.

\section{DAFTAR PUSTAKA}

\section{Pustaka Primer (Jurnal)}

Baker, W. E. \& Sinkula, J. M. (2009). The complementary effects of market orientation and entrepreneurial orientation on profitability in small businesses. Journal of Small Business Management, 47(4), 443-464.

Barney, J. (1991). Firm resources and sustained competitive advantage. Journal of Management, 17(1), 99-120.

Basso, O., Fayolle, A., \& Bouchard, V. (2009). Entrepreneurial orientation: the making of a concept. The International Journal of Entrepreneurship and Innovation, 10(4), 313-321.

Carter, S. L. (2003). Entrepreneurship in the farm sector: indigenous growth for rural areas. In Entrepreneurship in Regional Food Production, pp. 23-50. Norland Research Institute, Bodo, Norway.

Covin, J. G. \& Slevin, D. P. (1988). The influence of organization structure on 
the utility of an entrepreneurial top management style. Journal of Management Studies, 25(3), 217-259.

Covin, J. G. \& Slevin, D. P. (1989). Strategic management of small firms in hostile and benign environments. Strategic Management Journal, 10(1), 75-88.

Dana, L. P. \& Dana, T. E. (2007). Collective entrepreneurship in a Mennonite community in Paraguay. Latin American Business Review, 8(4), 82-96.

Dumasari (2014). Kewirausahaan Petani Dalam Pengelolaan Bisnis Mikro di Pedesaan. Jurnal Inovasi dan Kewirausahaan, No 3 Vol 3 September 2014.

Galdwin, T. N., Kennelly, J. J., \& Krause, T. S. (1995). Shifting paradigms for sustainable development: implications for management theory and research. Academy of Management Review, 20(4), 874-907.

Han, J. K., Kim, N., \& Srivastava, R. K. (1998). Market orientation and organizational performance: is innovation a missing link? Journal of Marketing, 62(4), 30-45.

Lauwere, C. C. (2004). The role of agricultural entrepreneurship in Dutch agriculture of today. Agricultural Economics, 33(2), 229-238.

McElwee, G. (2006). Farmers as entrepreneurs: developing competitive skills. Journal of Developmental Entrepreneurship, 11(3), 187-206.

McElwee, G. (2008a). Literature review and segmentation framework. In Ch. Rudmann (ed.), Entrepreneurial skills and their role in enhancing the relative independence of farmers. Results and recommendations from the research. Project Developing Entrepreneurial Skills of Farmers (pp. 19-26). Frick: Research Institute of Organic Agriculture FiBL.

McElwee, G. (2008b). A taxonomy of entrepreneurial farmers. International
Journal of Entrepreneurship and Small Business, 6(3), 465-478.

McElwee, G., \& Bosworth, G. (2010). Exploring the strategic skills of farmers across a typology of farm diversification approaches. Journal of Farm Management, 13(12), 819-838.

Mesquita, L. F. \& Lazzarini, S. G. (2008). Horizontal and vertical relationships in developing economies: implications for SMEs' access to global markets.

Academy of Management Journal, 51(2), 359-380.

Nieuwenhuis, L. F. M. (2002). Innovation and learning in agriculture. Journal of European Industrial Training, 26(6), 283-291.

Pyysiäinen, J., Anderson, A., McElwee, G., \& Vesala, K. (2006). Developing the entrepreneurial skills of farmers; some myths explored. International Journal of Entrepreneurial Behavior Research, 12(1), 21-39.

Rudmann, Ch., Vesala, K. M., \& Jäckel, J. (2008). Synthesis and recommendations. In Ch. Rudmann (Ed.), Entrepreneurial skills and their role in enhancing the relative independence of farmers. Results and recommendations from the research. Project Developing Entrepreneurial Skills of Farmers (pp. 85-108). Frick: Research Institute of Organic Agriculture FiBL.

Schumpeter, J. A. (2005). Development. Journal of Economic Literature, 43, 108120.

Svetlicic, M., Jaklic, A., \& Burger, A. (2007). Internationalization of small and medium-sized enterprises from selected Central European economies. Eastern European Economics, 45(4), 36-65.

Vesala, K. M., Peura, J., \& McElwee, G. (2007). The split entrepreneurial identity of the farmer. Journal of Small Business and Enterprise Development, 14(1), 4863. 
Vesala, H. T. \& Vesala, K. M. (2010). Entrepreneurs and producers: Identities of Finnish farmers in 2001 and 2006. Journal of Rural Studies, 26(1), 21-30.

\section{Buku Teks}

Arikunto, S. (2002). Prosedur Suatu Penelitian: Pendekatan Praktek.Edisi Revisi Kelima. Penerbit Rineka Cipta. Jakarta.

Bernard Lonergan, (2001) . Hermeneutics and Method: The Universal viewpoint. University of Toronto Press.

Bruton, G. D., Ahlstrom, D., \& Obloj, K. (2008). Entrepreneurship in emerging economies: where are we today and where should the research go in the future. Entrepreneurship: Theory \& Practice, 32(1), 1-14.

Kreiser, P. M., Marino, L. D., \& Weaver, K. M. (2002). Assessing the psychometric properties of the entrepreneurial orientation scale: a multi-country analysis. Entrepreneurship: Theory and Practice, 26(4), 71-94.

Miller, D. (1983). The correlates of entrepreneurship in three types of firms. Management Science, 29(7), 770-91.

Sugiyono. (2012). Metode Penelitian Kuantitatif Kualitatif dan $R \& D$. Bandung : Alfabeta.

Van Der Ploeg, 2000. Rural Development : From Practises and Policies Towards Theory. Journal of the European Society For Rural Sociology, John Wiley \& Sons, Ltd.

\section{Prosiding}

Bergevoet, R. H. M., Giesen, G. W. J., Saatkamp, H. W., van Woerkum, C. M. J., \& Huirne, R. B. M. (2005). Improving entrepreneurship in farming: the impact of a training programme in Dutch dairy farming. Developing Entrepreneurship Abilities to Feed the World in a Sustainable Way. International Farm
Management Association. $15^{\text {th }}$ Congress, Campinas SP, Brazil. No. 24219.

Marsden, T. \& Smith, E. (2005). Ecological entrepreneurship: sustainable development in local communities through quality food production and local branding. Geoforum, 36(4), 440451.

Mukti, Gema (2017). Kecerdasan Kewirausahaan (Entrepreneurial Intelligence) Lulusan Fakultas Pertanian Universitas Padjadjaran Sebagai Pelaku Usaha Tani.

Disampaikan dalam Prosiding Seminar Nasional Peningkatan Produktivitas dan Daya Saing Komoditas Pertanian, Hasil Penelitian Agribisnis I, Universitas Galuh, $\mathrm{p}$ : 567-576

Shilul, Tukhas (2014). Pendidikan Entrepreneurship Sebagai Strategi Peningkatan Daya Saing Bangsa Dalam Menghadapi AEC. Disampaikan dalam Seminar Nasional "Antisipasi Kebijakan Perpajakan dalam Menghadapi ASEAN Economic Community 2015" 